\title{
DIVERSIFICATION OF GAS SUPPLIES AS A CORNERSTONE OF GAS SECURITY IN THE FRAMEWORK OF THE THREE SEAS INITIATIVE
}

\author{
Danylo Stonis ${ }^{1}$
}

\begin{abstract}
The article overviews approaches to the diversification of gas supplies in the framework of the Three Seas Initiative. The modern geopolitical situation in Eastern and Central Europe is characterized by transformation processes in the energy sector. Due to the implementation of decarbonization policy in the European Union and subsequent shift from coal as a main energy source, a need in alternative fuel sources, such as natural gas, emerges. Therefore, a significant increase in natural gas consumption is expected, which raises a number of issues, such as dependence on a single gas supplier and orientation of the EU's gas transmission system in East-West direction only. This issue is crucial for Eastern and Central European states, due to the underdeveloped gas infrastructure in the region and heavy dependence on a single gas supplier, such as Russia or Turkey. Hence, the Three Seas Initiative is considered as a powerful tool, designed to develop energy, transport and digital infrastructure of the region in the North-South direction, where one of the most potentially promising projects within the framework of the Three Seas Initiative is represented by the development of gas infrastructure, aimed at solving the diversification of supplies in the gas market in Eastern and Central Europe. The implementation of developed gas infrastructure and diversification of gas supplies consists of several regional projects that are relevant for those countries in the region in which they are implemented in particular and for all member states of the Three Seas Initiative in general. The main purpose of the implementation of these projects is the creation of a unified natural gas transportation infrastructure in Eastern Europe along the North-South axis. The result of such a grand reorganization in the field of gas supplies to Europe will be an increase in the number of independent suppliers in the European gas market and a decrease in the dependence of the EU countries on gas supplies from Russia. In the article, the author traced in detail the tendency of the formation of energy infrastructure along the North-South axis with focus on the projects that are being implemented by each of the participating countries within the framework of the Three Seas Initiative. This approach allows to assess the scale and integrity of the gas transportation infrastructure, that is being created in the Eastern Europe region and its contribution to the common European energy security policy.
\end{abstract}

Key words: Three Seas Initiative, North-South axis, diversification, gas transportation system, energy security.

JEL Classification: F52, P48

\section{Introduction}

The Three Seas Initiative (TSI) is an ambitious project in the Central and Eastern European states, which offers great opportunities for the development of energy, transport and digital infrastructure in the countries of the region. It is an international forum that includes 12 member states of the European Union between the Baltic, Adriatic and Black Seas (BABS): Austria, Bulgaria, Croatia, the Czech Republic, Estonia, Hungary, Latvia, Lithuania, Poland, Romania, Slovakia and Slovenia. After the first TSI forum in Dubrovnik, the Three Seas Initiative is becoming a new format for strengthening cooperation between the EU member states from Central and Eastern Europe, the ultimate goal of which is to increase their economic and political opportunities, as well as to ensure security and sovereignty within the European Union.

The geopolitical situation in the region requires the development of a new energy security policy. If we look at the TSI member states, most of them are former members of the Soviet sphere of influence (were incorporated in the USSR or were members of the Eastern Bloc and acted as satellites of the USSR). As a result, all TSI member states, except Austria, were closed off from the rest of Europe by the USSR's Iron Curtain. This has led to the fact that the EU member

\footnotetext{
Corresponding author:

${ }^{1}$ Charles University in Prague, Czech Republic.

E-mail: daniell486486@gmail.com

ORCID: https://orcid.org/0000-0002-4771-0144
} 
states, which are located between the Baltic, Adriatic and Black Seas, do not have a common infrastructure with other EU countries in terms of energy and transport. Despite the aforementioned, the unifying element of TSI is the development of energy, transport and digital infrastructure between states in the Baltic, Adriatic and Black Sea regions, as well as between the EU member states in Eastern, Central and Western Europe. Another key feature of TSI is the diversification of energy supplies as part of an energy security policy, which aims to ensure that TSI member states can obtain natural gas from a variety of sources. In addition to this, the concept of informal platform was introduced, which allows to secure political support and facilitate specific cross-border and macro-regional projects in order to improve connections between northern and southern Europe through energy and infrastructure projects (Maćešić and Manovelo, 2016).

The purpose of this article is to provide an overview of the energy projects that are being implemented in the Three Seas Initiative framework. This overview focuses on a number of priority gas infrastructure projects that could shift the focus of regional energy discussions related to security of natural gas supplies to Europe. The main issue is that for over a decade, in both the EU and the TSI member states, natural gas supplies still remain an important energy source of the TSI region. Therefore, in the next decade, security of supply and large investments in the development of natural gas infrastructure are among the top priorities on the TSI agenda.

One of the major problems in the region is related to the EU's decarbonization policy, which requires a deep transformation process in the energy sector. Eastern European countries may have to come up with national commitments for renewable energy and energy efficiency goals in line with the new EU regulations and reflect them in their national energy system and climate action plan. If these energy and climate plans are implemented and a significant number of coal units in the region are closed down, there will be a need for alternative energy sources, such as natural gas, which will act as a transition fuel. Consequently, as a result of the significant decline in domestic energy production in the TSI region, energy security issues will be largely linked to natural gas imports.

This overview pays great attention to assessing the formation of a new energy infrastructure for gas supplies to Europe and its role in energy security. The TSI region is highly dependent on gas for several reasons. While domestic gas consumption in households may decline due to investment in energy efficiency and the growing share of electric heating, natural gas is expected to remain an important fuel source for the industrial sector as well as for electricity generation.

The implementation of energy projects, initiated within the framework of the Three Seas Initiative, will help stimulate economic growth in the region, develop the North-South infrastructure corridor and eliminate regional imbalances within the $\mathrm{EU}$ in order to achieve cohesion and unity in Europe. Currently, most of the region's strategic infrastructure, including road and rail infrastructure, runs along the East-West corridor. Transportation routes, highways, railways and gas pipelines all stretch from east to west, and therefore it is in the interests of the region to create analogical routes in the North-South direction. Therefore, the implementation of projects under the Three Seas Initiative has great potential for diversifying the energy market in Europe and strengthening its energy security.

\section{Region of the Three Seas Initiative, as a zone of opportunities for the diversification of energy supplies}

The fundamental goal of the Three Seas Initiative is to provide a sufficient political and economic basis for the implementation of specific strategic cross-border projects, hence enhancing transatlantic cooperation between TSI member states, stimulating economic prosperity and bringing EU to stronger cohesion. In order to achieve this goal, it is crucial for TSI member states to include not only the participation of governments, but also private companies that are interested in the development of the region and seek to invest in priority projects, thereby contributing to the overall goal of the Three Seas Initiative, which is designed to facilitate achieving real convergence among the EU member states, helping participating states to the Three Seas Initiative to get closer to the economic development level of the other EU member states, thereby contributing to enhanced EU unity, increased EU cohesion and coherence, further EU integration, as a basis for the re-launching of the European project (TSI, 2018).

However, despite the region's economic and infrastructural development, the Three Seas Initiative has a strong political agenda. Thus, the ultimate political goal of the Three Seas Initiative may be the creation of a new North-South corridor, which will ensure the geopolitical and energy security of the participating countries, as well as ensure the further development of new technologies, attract a large number of new investors to the region and lead to diversification of oil sources and gas in the region. During the third TSI Summit in Bucharest in 2018, one of the main goals of the TSI member states was "to contribute to the economic development of their States and of the region through better connectivity in the transport, energy and digital fields, especially on the North-South axis, thus boosting economic relations, energy security, trade and investment flows in the region and with other partners from the Euro-Atlantic community" (TSI, 2018).

According to Pierre-Emmanuel Thomann (2019), the main idea of the TSI is to develop infrastructure 
for energy and transport along the main North-South axis because the current infrastructure is oriented in the East-West direction. It is planned, that financing of these ambitious goals will be carried out not only by the participating countries of the Three Seas Initiative, but also through the attraction of private capital. Above average economic growth in the region, together with government support, will act as an incentive to attract private capital, allowing TSI to achieve its goals.

This overview aims to show that, despite the significant differences in TSI projects, they all have one common goal: to diversify the supply of gas energy in order to strengthen the energy security policy in the TSI region and to create a North-South axis that will act as a key supply line in the region aimed at creating a developed economic cluster that will connect all TSI member states into a single intertwined infrastructure.

This approach to the development of the Eastern European region is relevant in spite of Europe's decarbonization policy and the potential future role of natural gas as a transitional fuel, resulting in a growing dependence of TSI member states on gas imports. Today, Russia occupies a large share of gas imports to Europe. Russia's share in imports will grow from 34\% in 2017 to almost $40 \%$ by 2030 on an EU level (Diallo's et al study (based on REKK modeling, 2018).

However, the degree of dependence on Russian gas supplies in the countries participating in the Three Seas Initiative is not the same. For Central European states such as the Czech Republic, Slovakia, Slovenia and Croatia, a significant number of alternative gas sources are available. There are fewer alternatives for the Baltic states, Hungary, Romania, and Bulgaria, while Poland is currently unable to meet its demand without Russian gas. The diversification of energy supply routes is aimed at connecting the TSI member countries to the global LNG market through regasification terminals in Poland (Swinoujscie) and Croatia (Krk Island), with Norwegian fields through the Baltic Pipe, and also with Romanian offshore gas fields through the RomanianHungarian Interconnector.

It should be noted that almost one third of the priority projects $(32 \%)$ of the Three Seas Initiative are related to energy, which underlines the relevance of this overview (TSI, 2020). The projects presented in the overview include the construction of several LNG terminals, which will allow to receive more supplies of liquefied gas, thereby diversifying the number of energy supply sources and transportation routes to ensure energy security in the Three Seas region. This includes the LNG terminal on the island of Krk in Croatia, the Paldiski LNG terminal in Estonia and the Skulte LNG terminal in Latvia. In addition, energy projects include several new gas pipelines that will provide direct and cost-effective transportation of natural gas not only between the Three Seas region and Western Europe
(GIPL, BRUA), but also between the Middle East and the EU as a whole (Eastring).

Each TSI member state has selected its own set of projects for investment and participation. Some of these projects include several states of the Three Seas region, while others are designed specifically for a particular state for its own needs. Nevertheless all these priority projects share one common goal: to create a new North-South axis in the EU, which will act as a new EU market for investment and innovation, as a tool for developing sustainable energy policies by diversifying gas supplies, thereby reducing the EU's dependence on a single gas supplier such as Russia or Turkey.

\section{Overview of energy projects aimed at diversification of gas supplies in the TSI region}

An overview of energy projects within the framework of the Three Seas Initiative, formed with the aim of following how the implementation of projects in different countries contributes to the creation of the North-South gas transmission energy axis. The first priority project is represented by the regional LNG terminal in Paldiski, Estonia.

The construction of an LNG terminal in Paldiski is an investment project ordered by the Baltic States and Finland. Its main function is to receive liquefied natural gas, which will be delivered by tankers, store LNG in storage tanks and pump it as natural gas into a high-pressure distribution pipeline. The terminal is planned to be located in a strategically important place, namely in the middle of the future regional Baltic and Finnish energy markets, therefore the LNG terminal in Paldiski will be located between the Baltic States and Finland (Balticconnector), and will function as a link between the Finnish, Estonian and Latvian gas markets. The Estonian company Alexela Group will participate in the construction of the terminal.

In 2018, a Memorandum of Understanding was signed between the Port of Tallinn and Alexela Group, which will propose solutions for the construction of a terminal and maintenance of tankers and LNG bunkers, as well as the creation of port facilities for loading and unloading of liquefied natural gas (Greenport, 2018). The total project cost is estimated at 400 million EUR (TSI Projects, 2020).

According to a study completed under the Baltic Energy Market Interconnection Plan (BEMIP), the construction of an LNG terminal in Paldiski will have a positive impact on the gas market of the Baltic States. The study noted that the construction of an LNG terminal in Paldiski in conjunction with the Balticconnector would improve security of supply both in Estonia and Finland and would also activate competition on the wholesale market of gas. Taking into consideration the regional gas market, the LNG terminal, with possible 
location in Paldiski, would be of regional importance (BEMIP, 2012).

The next project is represented by the Skulte LNG terminal construction project in Latvia. The main goal of this project is the development of an economically viable terminal for liquefied natural gas in the Skulte port area near Riga. Its main feature is the possibility of a direct pipeline connection with the Inčukalns underground gas storage (Inčukalns UGS). The main advantage of this project is that there is no need to build a cold storage facility, because the subsea and onshore pipelines are connected to the Inčukalns UGS facility, which makes this LNG terminal the most costeffective entry point for LNG to the Baltic and Finnish markets. At the same time, given the low capital costs of the terminal construction, one should count on a low regasification tariff in the entire Baltic Sea region. This result will attract gas trading companies and large consumers to buy gas on the spot market and open up the possibility of alternative gas supplies in relation to Russian gas supplies on the Baltic gas market.

In turn, the Skulte LNG terminal will stabilize natural gas and energy supplies to Latvian consumers and will strengthen Latvia's energy security. In addition to the aforementioned, the Skulte LNG terminal together with the Klaipeda LNG terminal and two Estonian projects in Paldiski and Tallinn are considered as a long-term solution for LNG import to the Baltic region. Moreover, the Skulte LNG terminal is considered the most competitive LNG import terminal project in the region as it will play a decisive role in the supply of gas to the Baltic gas market. According to the inter-TSO compensation agreement between the gas transmission operators in Finland, Estonia and Latvia, from the beginning of 2020, a single tariff zone for gas transportation was introduced for Finland, Estonia and Latvia. As a result, the supply of natural gas to and from the Inčukalns UGS facility will be supported without additional entry/exit fees (Conexus Baltic Grid, 2019). The total project cost is estimated at 120 million EUR (TSI Projects, 2020).

In general, the implementation of the Skulte LNG terminal project will reduce the dependence of the Baltic region on gas supplies from Russia, increase the diversification of gas supplies and increase their flexibility to accelerate the integration of the Baltic gas market and direct connection to European natural gas centers.

The next priority project considered is the GIPL Project - a TSI project, which consists of a natural gas pipeline and auxiliary infrastructure. This gas pipeline is designed to connect the Polish and Lithuanian, Finnish and Baltic natural gas transportation systems to the continental gas system of the European Union. The GIPL gas pipeline will be bi-directional in order to maintain the reverse gas flow. It is planned that by the end of 2021 a gas corridor between Poland and
Lithuania will be created. The significance of the project is confirmed by the fact that GIPL was selected by the European Commission as a project of common interests (PCI). (Official Journal of the European Union, 2020).

The most important role of this gas pipeline in the creation of the North-South energy infrastructure corridor in the TSI region is aimed at eliminating the energy isolation of the Baltic countries from the EU and in ensuring sustainable competition in the gas market. Following the commissioning of the Balticconnector gas pipeline, which connects Estonia and Finland, the GIPL connection will encourage consumers in the Baltic States and Finland to buy and sell gas competitively at the best price and make even more efficient use of the capacity of the LNG terminal by transporting gas along the new North-South corridor (Amber Grid, 2019).

The importance of the GIPL project for the Baltic states was stressed by Lithuanian Energy Minister Žygimantas Vaičiūnas (2020) in a following statement:

The international gas pipeline GIPL will not only be a pipeline between Lithuania and Poland, but will also become the main artery connecting gas markets throughout the EU, the Baltic countries and Finland. Thus, the process of developing a single European gas market will be completed in our region, and Lithuania, as well as the other Baltic countries, will have complete freedom of choice regarding gas supplies. The most important thing today is adherence to a pre-set schedule with fast progressing construction work and completion of the project by the end of 2021 as planned (Newsroom, 2020).

The GIPL gas pipeline is included in the BEMIP Gas Network, which is designed to connect the Baltic countries with the gas market of continental Europe. The creation of such an interconnected gas network like BEIMP in the EU is one of the top priorities not only for the TSI region, but also for Europe as a whole. According to Climate and Energy Commissioner Miguel Arias Cañete, "diversification of energy sources and routes, as well as unification of energy markets, is at the heart of the Energy Union. This is the key to ensuring safe, affordable and sustainable energy for all the EU citizens" (Invest in Estonia, 2016).

The European Commission has included the GIPL gas pipeline in the list of projects of common interest (PCI), which means that the project can receive government funding in the form of grants through the Connecting Europe Facility (CEF) initiative (Official Journal of the European Union, 2020). The CEF has approved funding of 306 million EUR. Latvian and Estonian gas transmission system operators will also contribute to the financing of the project. The investment budget in Lithuania is 136 million EUR, but savings are expected. In June this year, the European Investment Bank provided a loan of up to 65 million EUR for the implementation of the GIPL. The project is funded not only by the EU, Lithuania and Poland, 
but also by Latvia and Estonia (Ministry of Energy of the Republic of Lithuania, 2020).

The next project in this overview is the BRUA gas pipeline - proposed by Romania and officially named "Development of the National Gas Transportation System in Romania along the Bulgaria-RomaniaHungary-Austria corridor." It is aimed at the development of gas transmission capacities through the unification of the national gas transmission systems of Bulgaria, Romania, Hungary and Austria.

Preparations for the project began in 2016, although the actual construction of the pipeline began in 2019 . The construction of the first phase of the pipeline is operated by the Romanian state company Transgaz (Tzanetakou, 2019). The construction of the pipeline is designed to increase the energy security of Southeast Europe by diversifying gas supply routes, thereby reducing the country's dependence on Russian gas supplies. The main goal to be achieved during the implementation of the BRUA project is to combine the gas transmission systems of Romania with the corresponding gas transmission systems of Bulgaria and Hungary. It is also planned that the pipeline will provide the TSI region with access to potential large panEuropean gas infrastructure projects such as the Trans Adriatic Pipeline (TAP). This pipeline will also allow bi-directional gas flow to maintain interconnection and therefore interdependence between the gas transmission systems of the BRUA project participants. According to Romanian Energy Minister Toma Petcu, "the pipeline will include reverse flow technology, which will allow natural gas to be pumped in any direction to meet needs during periods of peak demand or emergencies" (Sam, 2017).

An important factor for the implementation of the BRUA project is that the project will become part of the North-South gas connections in Central and Southeast Europe (NSI East Gas) and join the priority gas corridor, which includes gas infrastructure for regional connections between the Baltic Sea region, the Adriatic and the Aegean Seas, the eastern Mediterranean and the Black Sea, as well as within it.

Eastring is another new gas pipeline project presented by Slovakia in 2018. It will be part of a natural gas pipeline that connects Slovakia with the BulgarianTurkish border of the TSI region, as well as the EU, crossing the territories of Hungary and Romania. An important feature of this pipeline will be its bi-directional nature. This will make it possible to supply gas from the Black Sea region, the Caspian region and the Middle East. Accordingly, such a campaign presupposes diversification of gas supply sources to the TSI region, which enhances its energy security and independence.

The expected budget for the project is estimated at 2.06 billion EUR (TSI Projects, 2020). According to the chairman of the board of directors of Eustream, operator of the gas transmission system in Slovakia, the project will be financed mainly by clients who will use the pipeline, who will participate in financing the project through long-term contracts, part of the amount will be covered by the EU and a loan from the European Investment Bank or the European Bank for Reconstruction and Development. Finally, some of the resources will also come from the companies that will participate in the construction: Eustream in Slovakia, FGSZ in Hungary, Transgaz in Romania and Bulgartransgaz in Bulgaria (TSI Projects, 2020).

It should be noted that if for Lithuania, Latvia and Estonia participation in the projects of the Three Seas Initiative is mainly the strengthening of energy security and independence from one source of energy resources, then the interest of Slovakia in energy projects is slightly wider. This is due to the fact that Slovakia is one of the TSI members, whose energy security largely depends on the transit of gas from Russia, the Black Sea region, the Middle East and the Caspian region to Central and Western Europe. After the escalation of the conflict between Russia and Ukraine in 2014, negative expectations arose regarding the termination of gas transit through the Brotherhood pipeline, through which Russian gas is delivered to Europe via Ukraine and Slovakia (Mišík and Nosko, 2017). In spite of the aforementioned, the Eastring project is very important for Slovakia, as a measure to increase the energy security of the TSI member states.

In order to strengthen energy security, the Slovak operator of the Eustream gas transmission system proposed the development of the Eastring gas pipeline with the aim of a bi-directional connection of the Slovak gas transmission system with South and Eastern Europe (SEE) (Mišík and Nosko, 2017). Overall, the implementation of the Eastring pipeline will not only diversify gas transportation routes in Southern and Eastern Europe, thereby providing access to currently inaccessible LNG terminals in Europe for the Balkan states and Turkey, but will also contribute to the establishment of the North-South axis.

The next important route and a promising option for diversifying sources and routes of gas supply, is the HU-SI-IT (Hungary-Slovenia-Italy) Natural Gas Corridor project, which is planned to enable the transit of natural gas from Romania, as well as from other offshore gas resources of the Black Sea to Italy. Also, the aforementioned gas corridor can serve as an access point for Hungary and a number of other TSI member states, which can transfer natural gas directly to the Italian LNG market. The purpose of the corridor is to provide a natural gas supply route for the TSI region and parts of Southern Europe, as well as to provide Italy and Slovenia with access to Hungarian gas terminals. This gas corridor will also be bi-directional and will provide interconnection between the gas transmission systems of Slovenia and Hungary. The implementation of the project will expand opportunities for diversifying gas sources and 
gas supply routes that will allow access to LNG sources from the Adriatic region. For example, in the HU-SI-IT Gas Corridor project, auxiliary infrastructure will be available, which is designed to increase the diversification of entry points. This will provide an opportunity to choose the source of gas supply and will allow the use of regional storage facilities by enabling a reverse flow (bidirectional flow) (FGSZ, 2020).

The importance of the HU-SI-IT pipeline for the TSI region is of utmost importance due to the fact that in 2013 the project received the status of a project of general interest (PCI) in accordance with EU Regulation No. 347/2013. It was included in the second PCI list of the European Commission in 2015 as part of an update to the list that came into force in February 2016. In November 2017, it was again assigned PCI status in the third list, which came into force in April 2018 (Plinovodi, 2020).

The next priority project is represented by the expansion of UGS Chiren. It envisages a capacity increase of the only gas storage facility in Bulgaria. The project is aimed at modernizing UGS facilities in order to provide a system of large volumes of gas and ensure the quality of its storage. The relevance of the project is further stressed by the fact that after the gas crisis of 2009, when Russia stopped the supply of natural gas to Europe, Bulgaria had to deal with the problem of energy security, since there are no alternative sources of gas supply. Therefore, the need to expand and modernize the UGS Chiren facility is a very important strategic priority for Bulgaria, since gas storage facilities ensure gas safety during emergencies, provide uninterrupted operation of the gas transmission system and protect against economic losses in the event of supply disruptions. The increase in the capacity of the Bulgarian gas transmission system allows diversification of the supplier market, stimulating the pricing policy and the development of the regional gas market, thus creating positive conditions for the implementation of the Balkan Gas Hub project.

In addition to the impact of the project on the regional gas market, its contribution to the pan-European structure of gas supplies should be considered. The European Union strongly supports the development of a reliable gas storage infrastructure and the diversification of gas supplies. He also prioritizes market liberalization, including private sector participation in the transit, storage and trading of natural gas, which still remain under the management of the stateowned Bulgartransgaz. Thus, the Chiren UGS facility expansion project was included in the EU List of Projects of General Interest (PCI) dated November 18, 2015 under the number PCI 6.20.2. The project was included under the same number in the EU's Third PCI List, published on October 31, 2020 (Official Journal of the European Union, 2020). The project's listing gives Bulgaria the opportunity to obtain EU funding to modernize and expand its existing storage capacity. The expansion project is co-financed by the Connecting Europe Facility (CEF). So far, the total investment cost of the project is provided in the amount of 226.4 million EUR (TSI Projects, 2020).

The next very significant and promising project envisages the construction of an oil and gas terminal in the port of Ploče in Croatia.

The attractiveness of this project is that the Port of Ploče is located in a convenient geostrategic location at the intersection of traffic flows between the Adriatic and Mediterranean regions, as well as Central Europe. The potential significance of the construction of an oil and gas terminal in the port of Ploče is the possibility of distributing oil products through this terminal. The new terminal will enable a cheaper and safer import of petroleum products and LPG by sea, as well as the distribution of petroleum products to numerous markets in South-East Europe (Energia Naturalis, 2020). It is expected that the successful implementation of the project, which is created according to the highest safety standards, involving technologies that comply with the latest European environmental standards, will play an important strategic role in strengthening the security of the region's energy supply and smoothly integrate into the energy infrastructure along the North - South axis under the Three Seas Initiative.

The last significant energy infrastructure project in the TSI region is the creation of an LNG Terminal on the island of Krk with an evacuation pipeline. The project includes floating terminal for regasification of liquefied petroleum gas (LPG) in Croatia. The main goal of the project is to meet energy needs and improve the security of gas supply by creating a new gas supply route for the central and southern parts of the TSI region. In general, the project consists of an LNG terminal on the island of Krk for receiving, storing, reloading and regasification of liquefied natural gas, and the OmišaljZlobin gas pipeline. The Omišalj-Zlobin gas pipeline will allow gas to be transported from the LNG terminal towards Hungary via the existing gas transmission system. On January 1st 2020, the Krk LNG terminal began operating and accepted batch of LNG, delivered from United States (Reuters, 2021).

The LNG terminal on the island of Krk will play an important role in the diversification of natural gas supplies, as well as in strengthening the energy security of natural gas supplies to the central and southern parts of the TSI region. It should also be noted that this project will be part of the European Commission's Common Interest (PCI) projects under the NSI East Gas Priority Corridor.

According to European Commissioner Margrethe Vestager, "The new LNG terminal in Croatia will increase the reliability of energy supply and increase competition for the benefit of the citizens of the region. We have approved the support measures that will be 
provided by Croatia, as they are limited to what is necessary for the implementation of the project and are in line with our state aid rules" (Safety4Sea, 2019).

The total investment costs are estimated at a maximum of 233.6 million EUR, including: 159.6 million EUR for the purchase of FSRU vessels, 60 million EUR for the land works of the EPC and 14 million EUR for the land out of 100 million EUR provided by the government of the Republic of Croatia, 101.4 million EUR in EU grant and 32.2 million EUR in share capital. This final investment decision was made by the LNG shareholders in Croatia on January 31, 2019 (LNG Croatia, 2019).

It can be assumed that the successful implementation of the project will lead to the strengthening of the gas transportation infrastructure in Central and Eastern Europe, which will eventually become part of the NorthSouth gas transportation axis, which is necessary for a stable, safe and competitive single European market.

\section{Conclusions}

The overview of the priority projects, designed to diversify natural gas supplies in the TSI region, shows, that such projects as the creation of an LNG terminal in Paldiski, LNG Skulte in Latvia, the GIPL gas pipeline, the Eastring gas pipeline and the BRUA gas pipeline, the HU-SI-IT gas corridor, the expansion of the Chiren UGS facility, the construction of an oil and gas terminal in the Ploce port and the LNG terminal on the island of Krk will not only interconnect the gas markets of the TSI member states in the North-South direction, but also allows to transfer natural gas via Slovenia and Hungary to Western European gas system. This approach to expanding and diversifying gas markets in the NorthSouth and East-West directions will lead to an efficient connection of gas sources located in the Caspian region, the Black Sea region, newly built LNG sources in the Adriatic Sea (LNG terminal on the island of Krk in Croatia), and sources of gas in the Mediterranean region. The implementation of these projects will also result in numerous economic benefits. The overview shows the planned amounts of investments that will be attracted and directed for the implementation of these projects from both the governments of the interested states and from the European Union and private investors. This approach to financing shows the extreme interest of the TSI member states in the diversification of gas suppliers to ensure the rapid and flexible adaptation of the gas transportation infrastructure to the increasingly dynamic gas market in the region, which is characterized by gas transit needs, the volumes of which are difficult to predict.

By linking gas markets with various gas sources along the North-South gas transmission corridor, the TSI region will enhance the security of gas supply. This is a key aspect that will ensure energy independence by eliminating dependence on a single source. It should be assumed that the implemented energy projects on the formation of a gas transmission system on the North-South axis in the TSI region will make a significant contribution to improving the operation of the gas market in the region, as well as become the basis for regional security of gas supplies and the achievement of the goals of European energy policy.

\section{References:}

Amber Grid (2020). Gas interconnection Poland-Lithuania (GIPL). Available at: https://www.ambergrid.lt/en/ projects/gas-interconnection-poland-lithuania-gipl (accessed 25 January 2021).

BEMIP Gas Regional Investment Plan 2012-2021 (2012). European network of transmission system operators for gas. CEENERGYNEWS (2020). GIPL Pipeline to be completed in 2021 as planned. Available at: https://ceenergynews. com/oil-gas/gipl-pipeline-to-be-completed-in-2021-as-planned/ (accessed 26 January 2021).

Commission Delegated Regulation (EU) 2020/389 of 31 October 2019, amending Regulation (EU) No 347/2013 of the European Parliament and of the Council as regards the Union list of projects of common interest (2020). Official Journal of the European Union, Volume 63, 11 March 2020, pp. 1-20. Available at: https://eur-lex.europa.eu/ legal-content/EN/TXT/?uri=OJ:L:2020:074:TOC (accessed 25 January 2021).

Conexus Baltic Grid (2019). The gas TSOs of Finland, Estonia and Latvia have reached an agreement on inter-TSO compensation system. Available at: https://www.conexus.lv/press-releases/somijas-igaunijas-un-latvijas-psopanakusi-jaunu-brivpratigu-vienosanos-par-gazes-parvadu-kompensaciju-sistemu (accessed 25 January 2021).

Diallo A., Dézsi B., Denková A., Jakóbik W., Jordanova A., Kácsor E., Madleňák T., Misik M., Moskwik K., Oravcova V., Roszkowski M., Szabó L., Takácsné Tóth B., Törőcsik A. (2018). 'Beyond gas' - energy security issues in the V4 after 2020. Final Synthesis Report. Available at: https://www.amo.cz/wp-content/uploads/2018/12/ V4-Beyond-Gas-Beyond-2020-Final-Synthesis-Report.pdf (accessed 25 January 2021).

Energia Naturalis (2020). The port of Ploče. Available at: https://www.enna.hr/en/the-port-of-ploce-t3 (accessed Jan 282021$)$.

FGSZ (2020). HUSIIT project. Available at: https://fgsz.hu/en/about-fgsz/activities-business-policy/ international-projects/husit (accessed 27 January 2021).

GlobeNewswire (2019). Amber Grid signed the GIPL gas pipeline works contract. Available at: https://www.globenewswire.com/news-release/2019/12/23/1964126/0/en/Amber-Grid-signed-the-GIPLgas-pipeline-works-contract.html (accessed 26 January 2021). 
Greenport (2018). Estonia assesses LNG terminal possibility. Available at: https://www.greenport.com/news 101/ lng/estonia-assesses-lng-terminal-possibility (accessed 25 January 2021).

Invest in Estonia (2016). EU invests 187,5 million euro in first gas pipeline between Estonia and Finland. Available at: https://investinestonia.com/eu-invests-187-5-million-euro-in-first-gas-pipeline-between-estonia-and-finland/ (accessed 26 January 2021).

Joint Declaration of the Third Summit of the Three Seas Initiative (2018). Available at: http://three-seas.eu/pressreleases (accessed 25 January 2021).

LNG Croatia (2019). LNG terminal on the island of Krk. Status and project update. Available at: https://budapestlngsummit.hu/2019/download/Barbara-Doric_LNG-Croatia.pdf (accessed January 28 2021).

Maćešić M., Manovelo I. (2016). Croatia hosts forum on Three Seas Initiative to strengthen north-south corridor. International Law Office. Available at: https://www.internationallawoffice.com/Newsletters/Energy-NaturalResources/Croatia/Macesic-Partners/Croatia-hosts-forum-on-Three-Seas-Initiative-to-strengthen-north-southcorridor (accessed 25 January 2021).

Ministry of Energy of the Republic of Lithuania (2020). Halfway almost reached in the implementation of the GIPL project which will connect the Baltic region and Europe. Available at: https://enmin.lrv.lt/en/news/ halfway-almost-reached-in-the-implementation-of-the-gipl-project-which-will-connect-the-baltic-region-andeurope (accessed 26 January 2021).

Mišík Matúš, Nosko Andrej (2017). The Eastring gas pipeline in the context of the Central and Eastern European gas supply challenge. Nature Energy, Issue 2, pp. 844-848. Available at: https://doi.org/10.1038/s41560-0170019-6 (accessed 27 January 2021).

Morgan Sam (2017). Central-Eastern European pipeline gets go-ahead. Euractive.com. Available at: https://www.euractiv.com/section/energy/news/central-eastern-european-pipeline-gets-go-ahead/ (accessed 26 January 2021).

Plinovodi (2020). PCI 6.23. Hungary-Slovenia interconnection (Nagykanizsa-Tornyiszentmiklós (HU) Lendava (SI) - Kidričevo) information leaflet. Available at: http://www.plinovodi.si/media/4765/pciinformation-leaflet-623.pdf (accessed 27 January 2021).

Reuters (2021). Croatia kicks off LNG terminal in north Adriatic. Available at: https://www.reuters.com/ article / croatia-lng-idUSL8N2JC0FN?fbclid=IwAR3 cfNw192yDiILkDRzZU-eW-Oz-iDCiWkqTi-ua_ oHde052cfbhQLEqokM (accessed Jan 282021 ).

Safety4sea (2019). EU approves construction of Croatian LNG terminal at Krk island. Available at: https://safety4sea.com/eu-approves-construction-of-croatian-lng-terminal-at-krk-island/ (accessed January 282021 ).

Thomann, Pierre-Emmanuel (2019). The Three Seas Initiative, a New Project at the Heart of European and Global Geopolitical Rivalries. Rocznik Instytutu Europy Środkowo-Wschodniej [Yearbook of the Institute of East-Central Europe], Volume 17 (2019), Issue 3, pp. 31-63. doi:10.36874/RIESW.2019.3.3.

Three seas Initiative Business Forum. Enhancing European and transatlantic economic cooperation (2018). Available at: https://3si-business.com/about/ (accessed 25 January 2021).

Three Seas Interconnection Priority Projects (2020). Commissioning of the regional LNG terminal in Paldiski, Estonia. Available at: https://projects.3seas.eu/projects/commissioning-of-the-regional-lng-terminal-in-paldiskiestonia (accessed 25 January 2021).

Three Seas Interconnection Priority Projects (2020). Construction of a coastal LNG terminal. Available at: https://projects.3seas.eu/projects/construction-of-a-coastal-lng-terminal (accessed 25 January 2021).

Three Seas Interconnection Priority Projects (2020). Eastring. Available at: https://projects.3seas.eu/projects/ eastring (accessed January 2021).

Three Seas Interconnection Priority Projects (2020). UGS Chiren expansion. Available at: https://projects.3seas.eu/ projects/ugs-chiren-expansion (accessed 27 January 2021).

Three Seas Summit in Tallinn, Estonia. Three Seas Priority Projects in Numbers (2020). Available at: https://www.3seas.eu/about/progressreport (accessed 25 January 2021).

Tzanetakou Nefeli (2019). Romania: Construction of the BRUA pipeline to finally begin. Independent Balkan News Agency. Available at: https://balkaneu.com/romania-construction-of-the-brua-pipeline-to-finally-begin/ (accessed 26 January 2021). 